\title{
Ethnocentrism: A Common Human Failing
}

\author{
Wan Yongkun \\ Yuxi Teachers College, Yuxi Municipality in Yunnan Province of China 653100
}

Keywords: ethnocentrism; common human failing; relativism; multiculturalism; xenocentrism

\begin{abstract}
Ethnocentrism is a commonly used word in circles where ethnicity, inter-ethnic relations, and similar social issues are of concern. This paper initially examines main types and bad aftereffects of ethnocentrism, and shows that ethnocentrism is that all people impose the assumptions and perspective of our own culture upon all other situations that we counter, which can dangerously mislead to a few bad aftereffects. The possible overcoming of ethnocentrism is also suggested by the substitution of cultural relativism, multiculturalism (or polycentrism), and xenocentrism.
\end{abstract}

\section{Introduction}

It was not until 1906 that William Graham Sumner formalized the term into a social science concept, after which it soon gained wide usage throughout the world. The usual definition of the term is: a. the belief that one's own ethnic group or culture is fundamentally superior to others; $b$. a tendency to view alien groups or cultures from the perspective of one's own [1]. Ethnocentrism is examined in different ways and from different perspectives. Some scholars seek to describe ethnotrism as an individual psychological disposition which has both positive and negative outcome(Neuliep \& McCroskey, 1997)[2].Some tries to provide an integrative review of the antecedents and consequences of consumer ethnocentrism(Mahesh N. Shankarmahesh, 2006)[3] and lots of Chinese researchers stress ethnotrism’s historical, social and political effects.

\section{Main Types of Ethnocentrism}

\subsection{Eurocentrism}

Eurocentrism is the practice of viewing the world from a European perspective, with an implied belief, either consciously or subconsciously, in the preeminence of European (and, more generally, of Western) culture. The term Eurocentrism implies criticism of the concerns and values at the expense of non-Europeans and is not used by those who consider it factually justified. Eurocentrism was prevalent in international affairs in the 19th to 20th centuries, which has its historical roots in European colonialism and imperialism from the Early Modern period (16th to 18th centuries). Many international standards, such as the Prime Meridian, the Dionysian Era or the worldwide spread of the Latin alphabet, have their roots in this period. Cartesian maps have been designed throughout known history to center the northwestern part of Europe (most notably the Great Britain) in the map. In both Europe and North America, the heyday of Eurocentricism was in the 19th century, today it is much less prevalent due to a variety of economical, cultural and political factors in the whole world. Since the end of the World War II, the former worldwide dominance of Eurocentrism's influence has waned drastically.

\subsection{Sinocentrism}

Sinocentrism is any ethnocentric perspective that regards China to be central or unique relative to other countries. In pre-modern times, this took the form of viewing China as the only civilization in the world, and foreign nations or ethnic groups as barbarians. At the height of the Chinese empire, the Japanese, Koreans, Vietnamese, and Thai all believed China to be the center of the universe and referred to China as the middle kingdom. Within East Asia, the cultural and economic centrality of China was recognized and most countries submitted to the sinocentric model. Sinocentrism was not 
seriously challenged until contact with the European powers in the 18th and 19th century, in particular during the Opium War. This ideology suffered a further blow when Imperial Japan, having undergone the Meiji Restoration, defeated China in the First Sino-Japanese War. Thus, the Sinocentric model of political relations came to an end in the 19th century.

\subsection{Amricentrism}

During the 17th century, British settlers and immigrants from across Europe brought their Eurocentrism with them to America. After the American Revolution, the colonists' Eurocentrism merged into America. Americentrism, also called American Exceptionalism-a term coined by Alexis de Tocqueville in 1831, is the perception that the United States differs qualitatively from the European world as well as other countries around the world because of its unique origins, national credo, historical evolution, or distinctive political and religious institutions. It traditionally refers to the the belief that the United States, holding a special place in the world, is therefore the hope for humanity. However, this term can also be used in a negative sense by critics of American policies to refer to a willful nationalistic ignorance of faults committed by the American government.

\section{Bad Aftereffects of Ethnocentrism}

The word ethnocentrism derives from the Greek word ethnos, meaning "nation” or "people," and the English word center. Ethnocentrism is the tendency to look at the world primarily from the perspective of one's own ethnic culture. Ethnocentrism often entails the belief that one's own race or ethnic group is the most important or that some(or all) aspects of its culture are superior to those of other groups. With this ideology, individuals judge other groups in relation to their own particular ethnic group or culture, especially with concern to language, behavior, customs, and religion. It seems natural that people feel pride in the culture where they have grown up and from which they have adopted their values, standards of thought and behavior. So, everyone is perhaps ethnocentric, and there is no way not to be ethnocentric; ethnocentrism can't be avoided, nor can it be willed away by a positive or well-meaning attitude. In varying degrees, ethnocentrism is an attribute of ethnic groups, past and present, throughout the world. Ethnocentric people often judge what is different or strange to them to be bad, dumb, backward, pagan, primitive, etc.

\subsection{Ethnocentrism's omnipresence}

Ethnocentrism has been described as an individual psychological disposition which has both positive and negative outcomes: on the one hand, ethnocentrism serves as an antecedent towards "patriotism and willingness to sacrifice for one’s central group” (Neuliep \& McCroskey, 1997) and helps in constructing and maintaining one's cultural identity (Chen \& Starosta, 2004); on the other hand, ethnocentrism leads to misunderstandings (Neuliep \& McCroskey, 1997) and reduced levels of intercultural-willingness-to-communicate (Lin \& Rancer, 2003).

\subsection{Misjudges other peoples or distorts international relations}

A common idiom for ethnocentrism is "tunnel vision". Ethnocentrism causes people to make false (or wrong) assumptions about cultural differences or other people based on their own limited experience. People are ethnocentric when they use their cultural norms to make generalizations about other peoples' cultures and customs. Such generalizations-often made without a conscious awareness that we've used our culture as a universal yardstick - can be way off base and cause us to misjudge other peoples. Ethnocentrism also distorts international relations through one's own tinted glasses. People often feel ethnocentric while experiencing what some call culture shock during a stay in a different country.

Anglocentrism is a form of ethnocentrism specific to people who self-identifying as English, irrespective of such individuals genetic makeup, religious beliefs, or sexual orientation. From 18th to 20th centuries, the English nation surpassed other European nations and expanded from a small island into a global and colonial empire-the British Empire. It is often claimed that England 
defined the world's meridians with itself on the center line, so that to this day, longitude is measured in degrees east or west of Greenwich, thus establishing as fact an Anglocentrist's worldview. From the unique national name in the world, the United Kindom of Great Britian and Northern Ireland (rather, much prefered abbreviation - the Great Britian), we can feel the strong British sense of superiority. Moreover, especially during the whole 19th century, the British even crowned their own nation as the Empire on Which the Sun Never Sets [4].

The term Americentrism points to issues where a predominance of American point of view exists, to the detriment of a neutral or world view. Shortly after less than 250 years' development, invasion and expansion, the United States of America already became the sole superpower in the modern world. The United States has traditionally conceived of itself as having an unique role during the world history, famously characterized by President Abraham Lincoln as "the last, best hope of Earth”, an outlook that came to be known as American Exceptionalism. Due to its in-born national superiority, the heaven-endowed Redeemer mission and the super national power, America thinks itself as a model and the leader of the whole world, so today it is continuouly pursuing American hegemonism and ideals during the international relation, which has evoked other nations' antipathy and protest [5].

Chinocentrism often takes the form of according Chinese significance or supremacy at the cost of other nations. China's very name is composed of ideographs meaning "center" and "country" respectively, and traditional Chinese world maps show China in the center. Ancient China regarded itself the center of the world and viewed other nations as increasingly barbaric according to their degree of distance. According to the Chinocentric system, the barbarians in the east were called Dongyi, those in the west Xirong, those in the south Nanman, and those in the north Beidi. Surrounding countries, such as Japan, Korea, and Vietnam, were regarded as vassals of China and relations between the Chinese Empire and these peoples were interpreted as tributary relationships under which these countries offered tribute to the Emperors of China in exchange for their rulers' investiture, return bestowals, and merchants' special licences. Areas outside the Chinocentric influence were called huawaizhidi, meaning “uncivilized lands”. In a cultural sense, Chinocentrism refers to the tendency to regard Chinese culture as more ancient than or superior to other cultures. This often involves regarding neighboring countries as mere cultural offshoots of China. By the mid19th century, closed, arrogant and incompetent imperial China was well past its peak and was on the verge of collapse. In modern Chinese foreign policy, the People's Republic of China has stated repeatedly that it will never seek hegemony. While P.R.C. has renounced claims to superiority over other nations, some claim that China never really completely abandoned Sinocentrism and that a sinocentric view of history lies behind many modern Chinese constructs of history and self-identity, which is indeed a meaning pity.

\subsection{Causes racism, chaos, or even wars}

While a healthy dose of ethnocentrism will yield a proud, hard-working, productive, and innovative society, unchecked or perverted ethnocentrism can lead to racism, chaos, or even wars. Throughout history, warring factions have been composed of fairly homogeneous ethnic groups; ethnic strife is seen dominating the landscape in many parts of the world even till today.

Eurocentrism is a type of ethnocentrism which places emphasis on European culture and the western world at the expense of other cultures. Eurocentrism has often involved asserting that cultures not white or European as being inferior, or even denying their existence as true human. The World History taught in European schools frequently teaches only the history of Europe and the United States in detail, with only brief mention of events in Asia, Africa, and Latin America. The Eurocentrists considered those societies in Africa, Asia and America to be primitive in comparison to their progressive, rapidly growing society. They concluded that Europe was the only place in the world that had reached the final stage of social development. Thus, they thought of themselves as uniquely responsible for the scientific, technological, and cultural achievements that constituted "the modern world". By the nineteenth century, it was a widespread theory that European advancement had occurred because of racial superiority, which in turn provided justification for 
slavery and other political and economic exploitation.

Among some United States' citizens, Americentrism (American Exceptionalism) has come to suggest a moral superiority of the United States to other nations. Americentrism, in this sense, is merely an excuse by Americans to view the world (including America itself) in an ethnocentric manner. White Americans labored hard to create a system of race-based prejudice, violence, discrimination, or oppression in the 17th century and have worked diligently to maintain the system ever since. Today, as in the past, the United States can be characterized as "a total racist society" because racism is still used to organize every social institution. In the United States, foreigners and even immigrants have been referred to as aliens, and, when they did not hold legal status within the country, as illegal aliens, terms indicating the significant difference between American-born and other people.

Hanocentrism, also called Han chauvinism or Hanism, is a term which is used in mainland China and Taiwan referring to people carrying ethnocentric viewpoints that favor the Han Chinese majority ethnic group in China at the expense of the other minority ethnic groups, often under the assumption of cultural superiority. Those espousing chauvinistic attitudes often revive ancient pejorative terms to refer to other ethnic groups as barbarians, such as Nanman, Xirong, Beidi and Dongyi. Although the Han nationality are the majority ethnic group in China, making up an estimated $92 \%$ of the population, actions and speech that constitute the ethnocentric and ideological aspects of Han chauvinism(such as hate speech against minorities) are illegal in the People's Republic of China and are either banned or censored.

Germanocentrism is a form of ethnocentrism specific to people who self-identifying as Germans, irrespective of such individuals' genetic makeup, religious beliefs, or sexual orientation. Some expressions of ethnocentrism by ethnic Germans could more accurately be described as Eurocentrism. After 19th century, the process of Germany national consciousness appeared deviation and inclined towards the sense of Norman people's superiority, thus it was used by national militarist and fanatics; The unity of the Second German Empire resulted in another aggressive consciousness, which evolved into Chauvinism and Militarism; In the late 19th centrury, German economics developed more and more quickly and powerfully, which finally make this more aggressive consciousness combined with racialism and Fascism[6]. Therefore, two World wars broke out, which brought great disasters and had a deep effect on the whole world [7].

Japanocentrism is the ethnocentric belief that Japan is, or should be, at the center of the world. This may manifest itself domestically as the persecution and marginalization of non-Japanese, or globally as the pursuit of Japanese economic, cultural, or political hegemony. The belief that Japan has a central role to play in world politics, whether as a bulwark against Western hegemony or as a force in its own right, has been a central issue in Japanese politics, particularly for right-wing nationalists. Since the Meiji Restoration, the Japanese have formed a special national cultural mentality from the agricultural economic society to the industrial economic society, which expresses as ethnocentrism of selfishness, mental of power worship and inclination of collectivism[8]; the nation of Mikado dominating everything was established in Japan and it realized modernization very soon, meanwhile the theory despising China and other Asia countries also emerged as the times demanded[9]. Japanocentrism had a galloping expansion in the modern times, which was divorced from the rational track and ultimately fell to a military aggrandizemen [10], which had caused very grave disasters to the people around the world.

\section{Possible Overcoming of Ethnocentrism}

\subsection{Cultural relativism}

Cultural Relativism is the view that individual beliefs and values systems are culturally relative. That is, no one ethnic group has the right to say that their particular system of beliefs and values, their worldview, is in any way superior to anyone else's system of beliefs and values. Cultural Relativism cliams that an individual human's beliefs and activities should be understood in terms of his or her own culture. What's right for one culture might be wrong for another and that's alright. 
There is no absolute standard of right and wrong by which to compare and contrast morally contradictory cultural values.

\subsection{Multiculturalism or polycentrism}

Multiculturalism is the belief that all cultures are equally viable, valid, and worthy of consideration. Multiculturalism is equivalent to forced social relativism, and requires the believer to deny that there are any ultimate truths when it comes to the plight of the human race. Polycentrism is the principle of organisation of a region around several political, social or financial centres. A county is said to be polycentric if its population is distributed almost evenly among several centres in different parts of the county.

\subsection{Xenocentrism}

Xenocentrism, the opposite of ethnocentrism, means preferring ideas and things from other cultures over ideas and things from your own culture. At the heart of xenocentrism is an assumption that other cultures are superior to your own. Of course, xenocentrism has to be greatly moderate and careful.

\section{Conclusion}

Ethnocentrism is a lens through which people examine other cultures. It is really a common human failing that can lead us to make false assumptions about cultural or ethic differences. A person may compare the morals, ethics, history, and religion of another country with their own, and decide that their own nation's practices are superior. This is the formation of an ethnocentric thought process. Ethnocentric people usually assume that their race, religion, culture, and nation are superior to all others. They impose the assumptions and perspective of their own culture upon all other situations that they encounter. The problem is that one may view other cultures not only as different, but also as inferior, with a great danger of behaving in ways that are damaging to those from other cultures. Consequently, improper ethnocentrim often results in misunderstanding among peoples or nations, and even terrible racial conflicts or wars.

Now, people ought to understand another culture in terms of itself rather than prejudging it as wrong, stupid, backward, etc., simply because it is different or unfamiliar. People who want to understand the world better should manage to overcome their own improper ethnocentrism. As increasing globalization bringing different cultures together, the world is becoming more connected, and people having greater access to information than at any other time, people around the world are learning to overcome their self-centered thinking, decrease their ethnocentric attitudes, and see human society from a broader and more inclusive perspective.

\section{References}

[1] G.M. Dalgish: Random's House Webster's Dictionary of American English (Foreign Language Teaching and Research Press, China 1998), p.1-1506.

[2] Q.W. Dong and others: Overcoming Ethnocentrism through Developing Intercultural Communication Sensitivity and Multiculturalism (In Chinese), Human Communication. 11 (2005) No.1, p.71-74.

[3] M.N. Shankarmahesh: Consumer Ethnocentrism: an Integrative Review of Its Antecedents and Consequences, International Marketing Review. 23 (2006) No.2, p.140-150.

[4] S.Z. Gao: The Origin and Roles of National Slurs (In Chinese), Journal of Jinang Normal University. 13(2002) No.3, p.58-63.

[5] S.Y. Liu: The Fundamental Contents and Background of the "Neo-Imperialism Theory" (In Chinese), Journal of Xinyang Normal University (Philos. \& Soc. Science edt.). 25(2002) No.3, p.11-14. 
[6] Y.C. Qin: The Awaking and Development of the Consciousness of Modern Germany Nation (In Chinese), Journal of Huainan Teachers College. 12(2001) No.4, p.46-48.

[7] D.F. Liu: The Formation of Germany Militarism Tradition (In Chinese), Journal of Mudanjiang College of Education. 109(2008) No.3, p.16-17.

[8] X.Y. Zhang: National Cultural Mentality Analysis for the War Self-Reflection of Japan (In Chinese), Journal of Beijing Institute of Education. 19(2005) No.1, p.14-19.

[9] C.P. Guo: On the Origin of Japanese Right Wing Trends of Thought and Its Evolving Locus (In Chinese), Journal of Xinzhou Teachers University. 20(2004) No.6, p.60-64.

[10] X.R. Yan: An Analysis of the "New Nationalism” in Japan (In Chinese), Journal of Xinzhou Teachers University. 16(2003) No.1, p.60-64. 